\title{
THE ANT LARVAE OF THE SUBFAMILY LEPTANILLINAE (HYMENOPTERA, FORMICIDAE)
}

\author{
By George C. Wheeler and Jeanette Wheeler \\ University of North Dakota, Grand Forks
}

The Leptanillinae are a small subfamily comprising 14 species in 3 genera: Leptanilla Emery, I I species; Leptomesites Kutter, I species; Phaulomyrma G. C. \& E. W. Wheeler, 2 species.

This subfamily has been recorded only from the warmer parts of the Old World: Corsica, Sardinia, North Africa, India, Malaya, Java, Queensland, Western Australia and Japan. Seemingly it is rare, but the paucity of the records may be due to minute size and hypogeic habits. As W. M. Wheeler optimistically remarked ( I932, p. 54) : "We should expect careful collecting with the Berlese funnel to bring additional forms to light in South Africa, Madagascar, Asia Minor and India, or even, perhaps, in the warmer parts of the New World." Brown ( 1954, p. 28) noted: "The habits of the species are such as to render their discovery highly fortuitous under present collecting methods." In the 30 years since Wheeler wrote, only two species have been discovered (one in India and one in Japan), which would rather support another statement by Wheeler in the same article (p. 57-58): "The Leptanillinae ... must be very ancient, like many other components of the microgenton. . . . L. swani is particularly interesting in this connection, because the extreme southwestern corner of Australia, in which it was taken, is known to possess the oldest and least disturbed fauna of any portion of the continent." Antiquity is compatible with a disjunct distribution and with rarity.

The genus Leptanilla was established by Emery in 1870 and then for half a century was kicked about over the taxonomic table. Originally Emery placed it in the "Dorylidae" near Typhlopone. Mayr, however, in a letter to Emery (date not given - see Emery 1904) dissented, maintaining that it belonged with the Myrmicinae. Emery was evidently convinced, for in 1875 he removed it to the "Mirmicidei" in the neighborhood of Stenamma and Liomyrmex. In I 877 he moved it to the vicinity of Monomorium and Leptothorax in the "Myrmicidei genuini" but marked it with a query to signify uncertain position. In I88 I Ern. André had it in the first tribe, "Myrmicidae verae," of the "Myrmicidae" but mentioned its affinities with the "Dorylides."

Forel in I893 did not mention the genus but might have meant 
to include it in the subfamily Myrmicinae, when he said that the fourth tribe ("Myrmicii") included "les autres genres de la sousfamille des Myrmicinae." And later (Igor) he excluded it from the Dorylinae when he says, "Donc, je maintiens la sous-famille Dorylinae limitée aux genres Dorylus, Aenictus, Eciton et Cheliomyrmex." In Dalla Torre's "Catalogus" ( I893) it was still in the Myrmicinae but near Trigonogaster and Pheidologeton. In I 895 Emery was still of the opinion that it belonged in the subfamily "Myrmicini" in the second tribe ("Myrmicii") near Huberia and Phacota. But nine years later (1904), after describing the female of $L$. revelierei, he returned it to its original subfamily (Dorylinae). In the following year in Ashmead's skeleton it stood between "?Liomyrmex" and Epipheidole in the tribe Stenammini, subfamily Myrmicinae, family "Myrmicidae." In I9O7 Santschi described males of 3 species, which he referred to the genus Leptanilla and claimed that their doryline affinities justified Emery's original allocation of the genus. It should be noted, however, that males of Leptanilla have never been taken with females or workers; hence it is not certain that those described by Santschi belong to this genus. In the "Genera Insectorum" Emery (I9IO) established for the genus a separate tribe (Leptanillini) in the subfamily Dorylinae, where it seemed destined to abide in isolation: Wheeler (I910), Forel (I917 and 1923), and Wheeler (I922) did not disturb it. Wheeler (I923, p. 335) suggested that even further isolation might be necessary: "I believe that the tribe Leptanillini, which Emery includes among the Dorylinae, will have to be separated out as a distinct subfamily (Leptanillinae). Dr. George C. Wheeler finds that the larva of Leptanilla is very aberrant, and the characters of the adult are either quite unlike those of other Dorylinae or only superficially similar and due to convergence, or similarity of subterranean habits." By 1932 (p. 57) the separation had been effected: "Emery, as is well known, regarded the Leptanillinae as constituting a special tribe of the Dorylinae, but Dr. G. C. Wheeler and I have raised the group to subfamily rank." Bernard (I95I) raised the taxon to family rank.

Brown and Nutting (I950, p. I24) in their study of the wing venation for the family Formicidae wrote: "The position of the leptanillines is debatable. They are usually treated as a subfamily by modern authors, and the venation is so highly reduced in the forms we have seen that little may be deduced from them concerning relationships to the other subfamilies." Brown was apparently still puzzled in 1954 (p. 28) for he wrote: "This little subfamily has suffered such drastic anatomical reduction in most of the usually 
valuable phylogenetic characters that it is doubtful whether we shall ever be certain of its true affinities. ... It is possible that forms as yet unknown will reveal their ancestry more clearly. Until that time, however, subfamily rank for the Leptanillinae may as well be maintained. Present opinion seems to favor relating this group to the Dorylinae."

The larvae of the Leptanillinae do bear certain resemblances to the known doryline larvae (Dorylus, Aenictus, Eciton, Cheliomyrmex): the long slender body and the small feebly sclerotized mandibles. On the other hand, they differ in the constriction at the metathorax, the long hairs on the abdomen, the absence of hairs on the head and the shape of the head. But these differences become trivial and insignificant beside the three which not only differentiate them from the Dorylinae, but also from all other known formicid larvae ( 60 genera): (I) the peculiar projection from the ventral surface of the prothorax; (2) the reduction of the spiracles from the normal ten pairs to a single pair, which is located on abdominal somite III; and (3) the shape and stance of the mandibles.

\section{Subfamily LePTANILLINAE Emery}

Elongate and very slender; slightly constricted at the metathorax; anterior end curved ventrally; remainder of body straight and clavate. With a curious complex structure projecting anteroventrally from the ventral surface of the prothorax. Only one pair of spiracles, located on abdominal somite III; each spiracle opening eccentrically on a naked circular area. Body hairs simple; the minute hairs very abundant and uniformly distributed; a few conspicuous long hairs sparsely scattered. Head naked and elongate. Antennae small, slightly raised, each with two sensilla. Labrum slightly broader than long, with the ventral border semicircular; posterior surface spinulose, with the spinules in rows. Mandibles apparently turned laterally (instead of medially, as is usual with ant larvae); feebly sclerotized; each with a rather long slender sharp-pointed apical tooth, which curves laterally; lateral (= outer) border furnished with several long slender sharp-pointed teeth; anterior surface with rows of spinules. Labium thin, flap-like and narrowed basally; lateral surfaces sclerotized; each palp a low ventrolateral projection bearing five sensilla.

Of all the ant larvae studied we have found the Leptanillinae the most difficult to process partly because of their small size but chiefly because of their extreme slenderness. A slender larva is more apt to collapse than a stout one. Furthermore the constriction at the metathorax aggravates the difficulty of cleaning and predisposes to breakage in that region. As a result processing has often left us only 
fragments to mount on slides. Fragments are all right - in fact, necessary for some parts - if none is lost and if they can be correctly oriented.

References. - W. M. Wheeler (1923, p. 335) used larval characters in establishing the subfamily (quoted above and also by G. C. Wheeler, I928, p. $88-89$ and referred to by G. C. and E. Wheeler, I930, p. 198).

G. C. Wheeler ( I928, p. 89) justified W. M. Wheeler's establishment of the subfamily. (Repeated G. C. and E. Wheeler, I930, p. I99.)

Kutter I948 p. 294: "Alle bis jetzt bekannt gewordenen Larven der Leptanillinae haben den teilweise chitinisierten, ventralen Thorakalanhang gemein, wie offenbar auch die Senkrechtstellung der Mandibeln, während der Besitz des als Tympanalorgan bezeichneten Organs noch nicht als typisch für alle Larven der Unterfamilie bezeichnet werden darf."

Bernard, I95I, p. IO4I: "Larves eucéphales, carnivores; nourries par les ouvrières."

\section{Genus Leptanilla Emery}

We are unable to separate Leptanilla generically from Leptomesites: the difference between the larvae of the two known species of the former are as great as the difference between either species and the larva of the latter. Therefore the subfamilial description will suffice for the genus.

Bernard (I95I, p. IOI 7 ) described primitive larvae and mentioned the larva of Leptanilla as an example.

Kutter (1948, p. 292) differentiated the two genera by the absence of the naked area around the spiracle ("tympanum") and the structure of the ventral prothoracic projection. As we show below, this distinction is no longer tenable.

The two species of Leptanilla differ with respect to the following characters: size and shape of terminal boss; complexity of ventral prothoracic projection; size and arrangement of long body hairs; shape of head; number of teeth and spinules on the mandibles; and the sclerotized band bordering the spiracular area.

\section{Leptanilla revelierei sardoa Emery}

(Fig. I-8)

Length approximately I.3 mm. Body elongate and slender; thorax slightly curved ventrally, slightly constricted at the metathorax; abdomen straight and clavate, the diameter increasing gradually to abdominal somite $\mathrm{V}$ and decreasing to the posterior end which is 


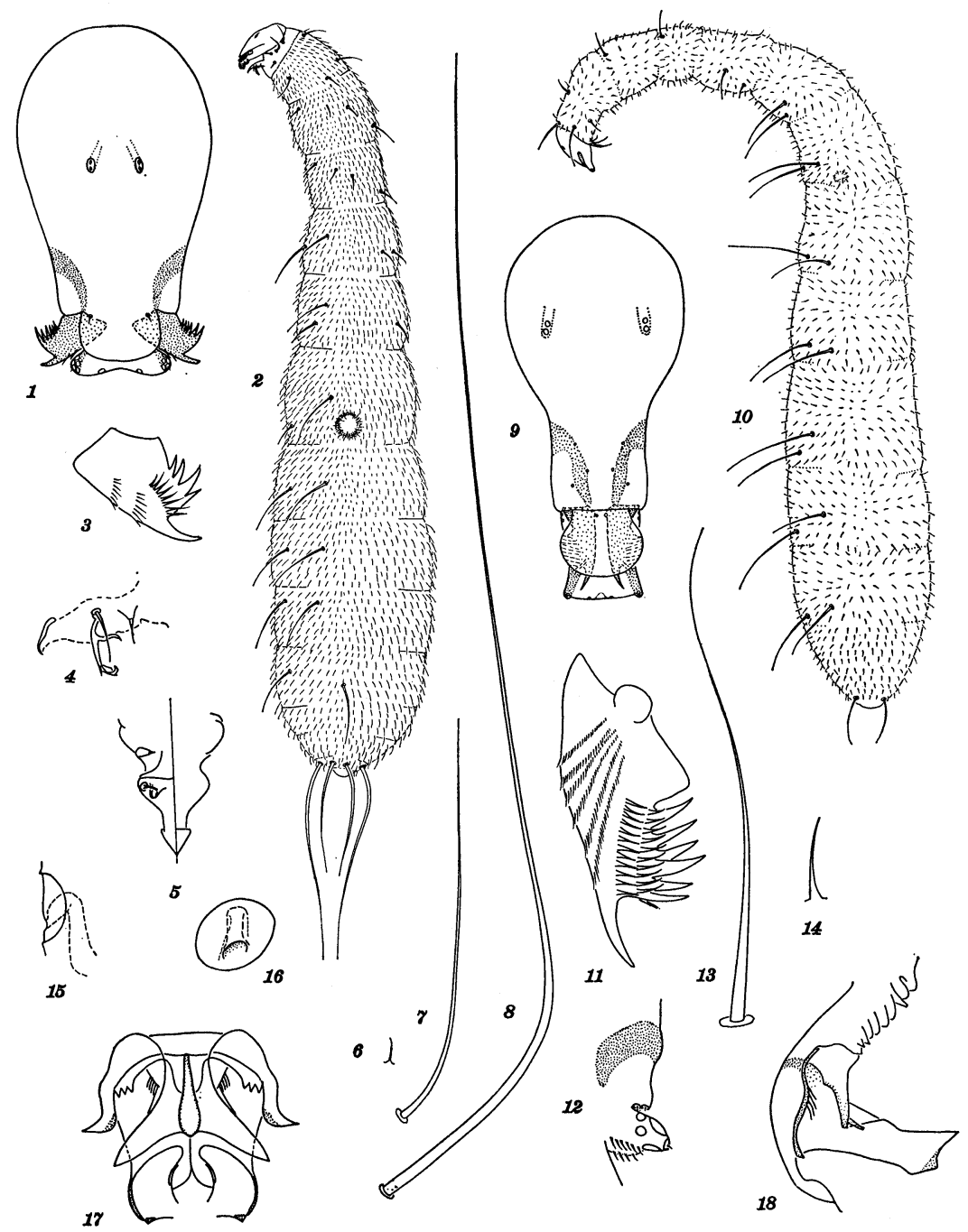

WheEler - Ant Larvae 
rounded and terminates in a small naked hemispherical boss. With a complex structure projecting anteroventrally from the ventral surface of the prothorax (see Fig. 4-5). With only one pair of spiracles, located on the third abdominal somite near the posterior border; each spiracle opening eccentrically on a naked circular area, which is bordered by a narrow heavily sclerotized band. Body hairs simple. Of three types: ( I ) numerous, increasing in length from $0.005 \mathrm{~mm}$ on the thorax to $0.02 \mathrm{~mm}$ at the posterior end, without alveolus and articular membrane, uniformly distributed but lacking from the anterior portion of the prothorax, the circumspiracular area and the terminal boss; (2) O.OI-O.I5 mm long (shortest on the prothorax), few, conspicuous, the longest attenuated and flexible distally, with alveolus and articular membrane, absent from the dorsal surface of abdominal somites III-IX; (3) about $0.3 \mathrm{~mm}$ long, with attenuated flexible tip, two (one dorsal and one ventral) on the posterior end near the terminal boss. Head naked; elongate; widest above the antennal level; cranium subpyriform in anterior view. Antennae small; slightly raised; each with two sensilla, each of which bears a spinule. Labrum slightly broader than long; the ventral border semicircular; posterior surface spinulose, the spinules in long rows, the rows concentric with the ventral border. Mandibles with the toothed border directed laterally; feebly sclerotized; each with a rather long slender sharp-pointed apical tooth, which is curved laterally; lateral border with four long slender sharp-pointed teeth; a few rows of rather large spinules on the anterior surface. Maxillae adnate to the labium; palp a stalked hemispherical knob directed laterally and bearing five sensilla; no galea seen. Labium a thin flap, narrowed basally; lateral surfaces sclerotized; each palp a low ventrolateral projection bearing five sensilla; an isolated sensillum between each palp and the opening of the sericteries; the latter a transverse impression on the anterior surface.

\section{Explanation of Plate 2}

Figs. 1-8. Leptanilla revelierei sardoa. 1 , head in anterior view, $\times 417$; 2 , larva in side view, $\times 76 ; 3$, left mandible in anterior view, $\times 847 ; 4$, ventral prothoracic structure in side view, $Х 423 ; 5$, ventral prothoracic structure: left half in posterior view, right half in anterior view, $X 423$; $6-8$, three body hairs, $\times 500$.

Figs. 9-18. Leptanilla swani. 9, head in anterior view, $Х 417 ; 10$, larva in side view, $\times 76 ; 11$, left mandible in anterior view, $\times 1333 ; 12$, left maxilla in anterior view, $\times 847 ; 13$ and 14 , two body hairs, $\times 500 ; 15$ and 16, spiracle and circumspiracular area in side and surface phantom views (hairs omitted) $\times 333 ; 17$ and 18 , ventral prothoracic structure in anterior view and in side view, $\times 667$. 
Material Studied. - Three larvae labeled "Sardegna: Golfo Aranci. I. I909 A. Dodero." These are the specimens studied by G. C. Wheeler ( I928). We studied them first with a phase microscope; then they were dismounted, stained lightly, remounted and studied under both phase and light microscopes.

Literature. The description and figures by G. C. Wheeler ( I928, p. 85-87) have been completely revised for this article. Bernard, I95 I, Fig. 949 C, D after G. C. Wheeler, I928.

\section{Leptanilla swani Wheeler}

(Fig. 9-18)

Length about $\mathrm{I} .4 \mathrm{~mm}$. Body elongate and very slender; anterior end curved ventrally, slightly constricted at the metathorax; remainder of body straight and clavate; diameter increasing gradually to abdominal somite VII and diminishing to the posterior end, which is round-pointed and terminates in a small naked boss. With a complex structure projecting anteroventrally from the ventral surface of the prothorax (see Fig. I7-18). With only one pair of spiracles, located near the posterior border of abdominal somite III; each spiracle opening eccentrically on a naked circular area. Body hairs simple. Of two types: (I) abundant and uniformly distributed (except on the terminal boss and the circumspiracular area), minute (0.005-0.024 $\mathrm{mm}$ long), longest near the posterior end, without alveolus and articular membrane; (2) long (0.084-0.23 mm), slender, with the apical portion fine and flexible, with alveolus and articular membrane, few, conspicuous, absent from the dorsal surface of the abdomen. Head naked; elongate; widest at the level of the antennae; cranium subpyriform in anterior view. Antennae small and slightly raised; each with two sensilla, each of which bears a spinule. Labrum slightly broader than long, with the ventral border semicircular; posterior surface spinulose, the spinules rather numerous and long, arranged in rows concentric with the ventral border. Mandibles with the toothed border directed laterally; feebly sclerotized; each with a rather long slender sharp-pointed apical tooth, which curves laterally; lateral border with six long slender sharp-pointed teeth; anterior surface spinulose, the spinules numerous, rather long and arranged in rows; posterior surface with one row of long spinules. Maxillae adnate to the labium; palp an irregular knob projecting laterally and bearing five sensilla; no galea seen. Labium a thin flap, narrowed basally; lateral surfaces sclerotized; each palp a low ventrolateral projection bearing five sensilla; an isolated sensillum between each palp and the opening of the sericteries; the latter a transverse slit on the ventral border. 
Material Studied. - Three larvae from Chittering, Western Australia collected by D. C. Swan. These are the specimens referred to by W. M. Wheeler in 1932 (p. 56-57). We studied them first with a phase microscope; then they were dismounted, stained lightly, remounted and studied under both phase and light microscopes.

In 1963 Rev. B. B. Lowery of St. Ignatius College (Sydney, Australia) generously sent us 40 larvae of this species, which he had collected at Cunningham's Gap in southern Queensland. The two best specimens have been kept in alcohol. Many others were processed according to our standard technique (1960) and studied under both phase and light microscopes.

Literature. W. M. Wheeler ( 1932, p. 56-57) compared the larva of $L$. swani with that of $L$. sardoa by quoting from a letter from G. C. Wheeler to whom he had sent the larvae for study.

\section{Genus Leptomesites Kutter}

As explained above under the genus Leptanilla, we are unable to separate Leptomesites generically from Leptanilla. Therefore our subfamilial description will have to suffice for this genus.

Kutter (1948, p. 287) has characterized the genus thus: "Körper sehr langgestreckt-zylindrisch, gegen das Ende keulenförmig aufgetrieben. Labrum ohne gezähnte, laterale Läppchen. Mandibeln abwärts gerichtet, gezähnt. Auf der Ventralseite des Prothorax mit breitem, in der Mittelpartie mit chitinisiertem, quergerilltem, lappigem Anhang. Beiderseits dieses einzigartigen Anhanges je eine sehr lange, sichelförmig ventralwärts gebogene Borste. (Ein Tympanalorgan, wie es von der Leptanilla-Larve gemeldet wird, konnte nicht mit Sicherheit nachgewiesen werden.)"

\section{Leptomesites escheri Kutter}

(Fig. 19-28)

Length about $\mathrm{I} .5 \mathrm{~mm}$. Body elongate and slender, apparently constricted at the metathorax; anterior end slightly curved ventrally; abdomen clavate, with the posterior end narrowly rounded. Projecting ventrally from the anterior portion of the prothorax is a curious flap-like structure furnished with I4 ridges on the posterior surface. Only one pair of spiracles present, on abdominal somite III (or IV?). Body hairs simple. Of two types: ( I) minute (0.009-0.026 mm long), longest near the spiracle, numerous, uniformly distributed, without alveolus and articular membrane; (2) short to very long $(0.042-0.096 \mathrm{~mm})$, a few on each somite, the apical portion fine and flexible, with alveolus and articular membrane. Head naked; elongate; widest above the antennal level; cranium subovoidal. Antennae small 

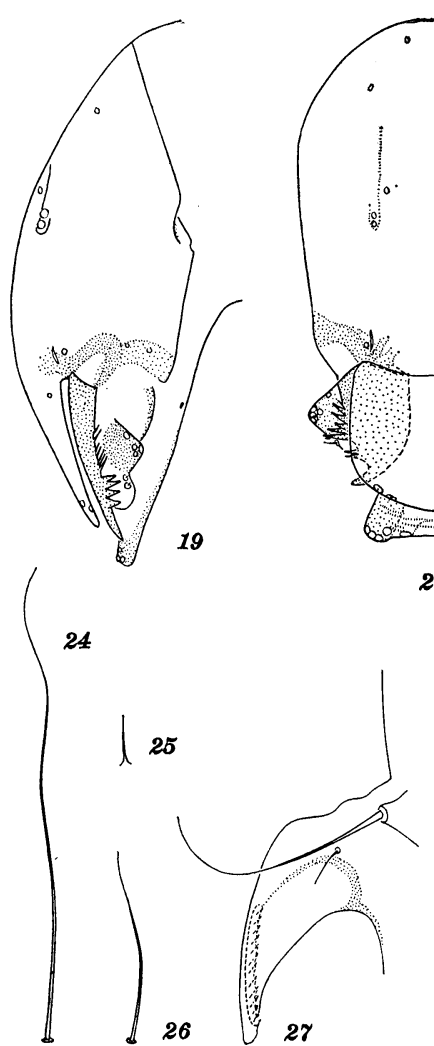

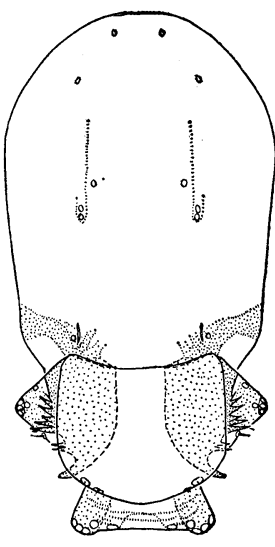

20

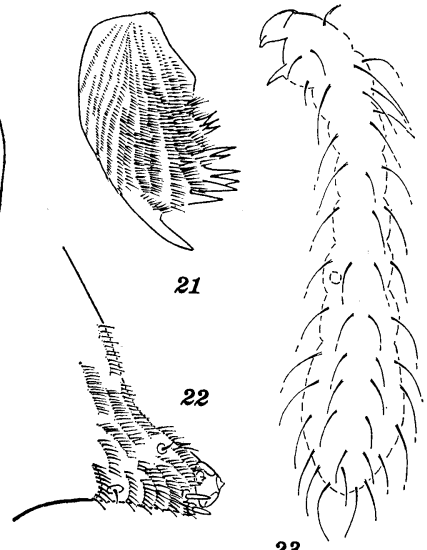

23

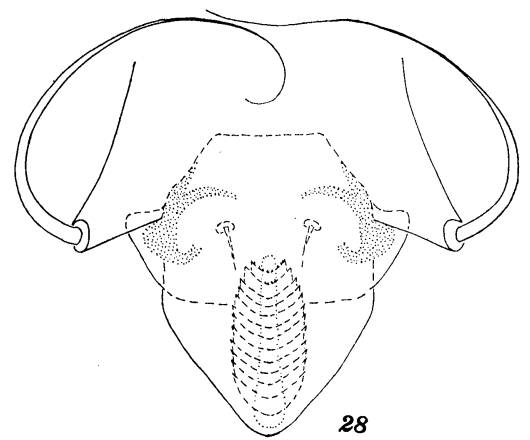

Figures 19-28. Leptomesites escheri. 19, head in side view, $Х 278 ; 20$, head in anterior view, $\times 278 ; 21$, left mandible in anterior view, $\times 423 ; 22$, left maxilla in anterior view, $\times 415 ; 23$, restoration of larva in side view (minute hairs omitted), $X 33 ; 24-26$, three body hairs, $\times 139 ; 27$ and 28 , ventral prothoracic structure in side view and in anterior view, $\times 272$.

and slightly raised; each with two sensilla, each of which bears a spinule. Labrum slightly broader than long; the ventral border semicircular; posterior surface spinulose, the spinules in long rows, the rows concentric with the ventral border. Mandibles with the toothed border directed laterally; feebly sclerotized; each with a rather long slender sharp-pointed apical tooth, which is curved laterally; lateral border with nine long slender sharp-pointed teeth; anterior surface furnished with numerous short rows of long spinules, the rows so close together that the spinules overlap. Maxillae conoidal, 
pointing laterally; palp apical and consisting of five sensilla; galea represented by two sensilla, each of which bears a digitiform spinule. Labium feebly bilobed, flap-like, narrowed basally; palp a low ventrolateral projection bearing five sensilla; an isolated sensillum between each palp and the opening of the sericteries; the latter a transverse slit on the ventral surface. Hypopharynx spinulose, the spinules in short transverse rows, the rows so close together that the spinules overlap.

Material Studied:- Two semipupae (?) from southern India. These are the specimens studied by Dr. Heinrich Kutter ( I948, p. 290-292) of Männedorf, Switzerland. In I963 we asked Dr. Kutter whether he would be willing to let us examine them. His generous response was to send them to us as a gift. We studied them first with the phase microscope; then they were dismounted, stained lightly, remounted and studied under both phase and light microscopes. We were not able to inflate the wrinkled specimens; therefore our drawing of the larva in side view is a restoration.

Literature. Kutter (1948, p. 290-292): a description of the species; Fig. 6, larva in side view; Fig. 7, anterior end enlarged.

André, ERn.

\section{Literature Cited}

1881-1882. Species des hyménoptères composant le groupe des formicides d'Europe, etc.

AshmeAD, W. H.

1905. A skeleton of a new arrangement of the families, subfamilies, tribes and genera of the ants, or the superfamily Formicoidea. Canad. Ent. 37: 381-384.

BERNARD, F.

1951. Super-famille des Formicoidea. In: P. P. Grassé (ed.), Traité de Zoologie, 10 (2): 997-1104. Masson et Cie, Paris.

BROWN, W. L.

1954. Remarks on the internal phylogeny and subfamily classification of the family Formicidae. Insectes Sociaux 1: 21-31.

Brown, W. L., and W. L. NutTing

1950. Wing venation and the phylogeny of the Formicidae. Trans. Amer. Ent. Soc. 75: 113-132, 2 pl.

Dalla Torre, K. W. von

1893. Catalogus Hymenopterorum hucusque descriptorum systematicus et synonymicus. Vol. VII: Formicidae (Heterogyna). W. Engelmann, Leipzig. 289 p.

EMERY, C.

1870. Studi mirmecologici. Boll. Soc. Ent. Ital. 2: 9 p, 1 pl.

1875. Le formiche ipogee con descrizioni di sp. nuove o poco note. Ann. Mus. Civ. Genoa 7: 465-474.

1877. Saggio di un ordinamento naturale dei myrmicidei e considerazioni sulla filogenesi delle formiche. Boll. Soc. Ent. Ital. 9: 1-17, 1 pl. 
1895. Die Gattung Dorylus Fabr. und die systematische Eintheilung der Formiciden. Zool. Jahrb. Abt. Syst. 8: 685-788.

1904. Le affinità del genere Leptanilla e i limiti delle Dorylinae. Arch. Zool. Napoli 2: 107-116.

1910. Fam. Formicidae, Subfam. Dorylinae in Wytsman's "Genera Insectorum." Fascicle 102: 34 p. 1 pl.

FOREL, A.

1893. Sur la classification de la famille des formicides, avec remarques synonymiques. Ann. Soc. Ent. Belg. 37: 161-167.

1901. A propos de la classification des fourmis. Ann. Soc. Ent. Belg. 45: 136-141.

1917. Cadre synoptique actuel de la faune universelle des fourmis. Bull. Soc. Vaud. Sci. Nat. 51: 229-253.

1923. Le monde social des fourmis du globe. 5: 174 p., 3 pls. Librairie Kundig, Geneva.

KUTteR, H.

1948. Beitrag zur Kenntnis der Leptanillinae. Eine neue AmeisengatSANTSCHI, F. tung aus süd-Indien. Mit. Schweiz. Ent. Ges. 21: 286-295.

1907. Fourmis de Tunisie capturées en 1906. Rev. Suisse Zool. 15: 305-334.

WHEELER, G. C.

1928. The larva of Leptanilla. Psyche 35: 85-91.

WheEler, G. C., AND Esther W. Wheeler

1930. Two new ants from Java. Psyche 37: 193-201.

Wheeler, G. C., AND JeanetTe Wheeler

1960. Techniques for the study of ant larvae. Psyche 67: 87-94.

WHEELER, W. M.

1910. Ants: Their structure, development and behavior. Columbia University Press, New York. 663 p.

1922. Ants of the American Museum Congo Expedition. Bull. Amer. Mus. Nat. Hist. 45: 1-1139.

1923. Social life among the insects. Harcourt, Brace \& Co., New York. $375 \mathrm{p}$.

1932. An Australian Leptanilla. Psyche 39: 53-58. 

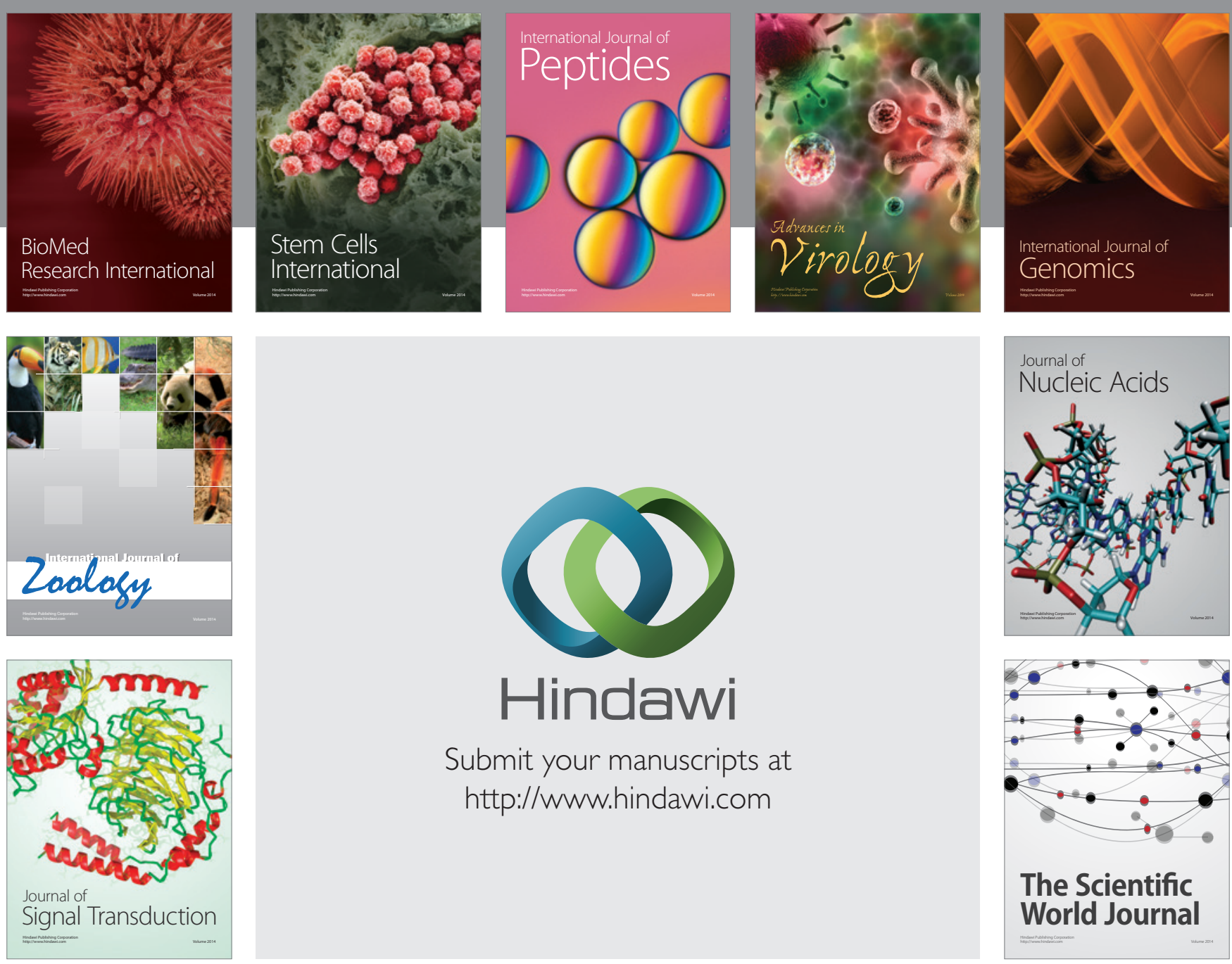

Submit your manuscripts at

http://www.hindawi.com
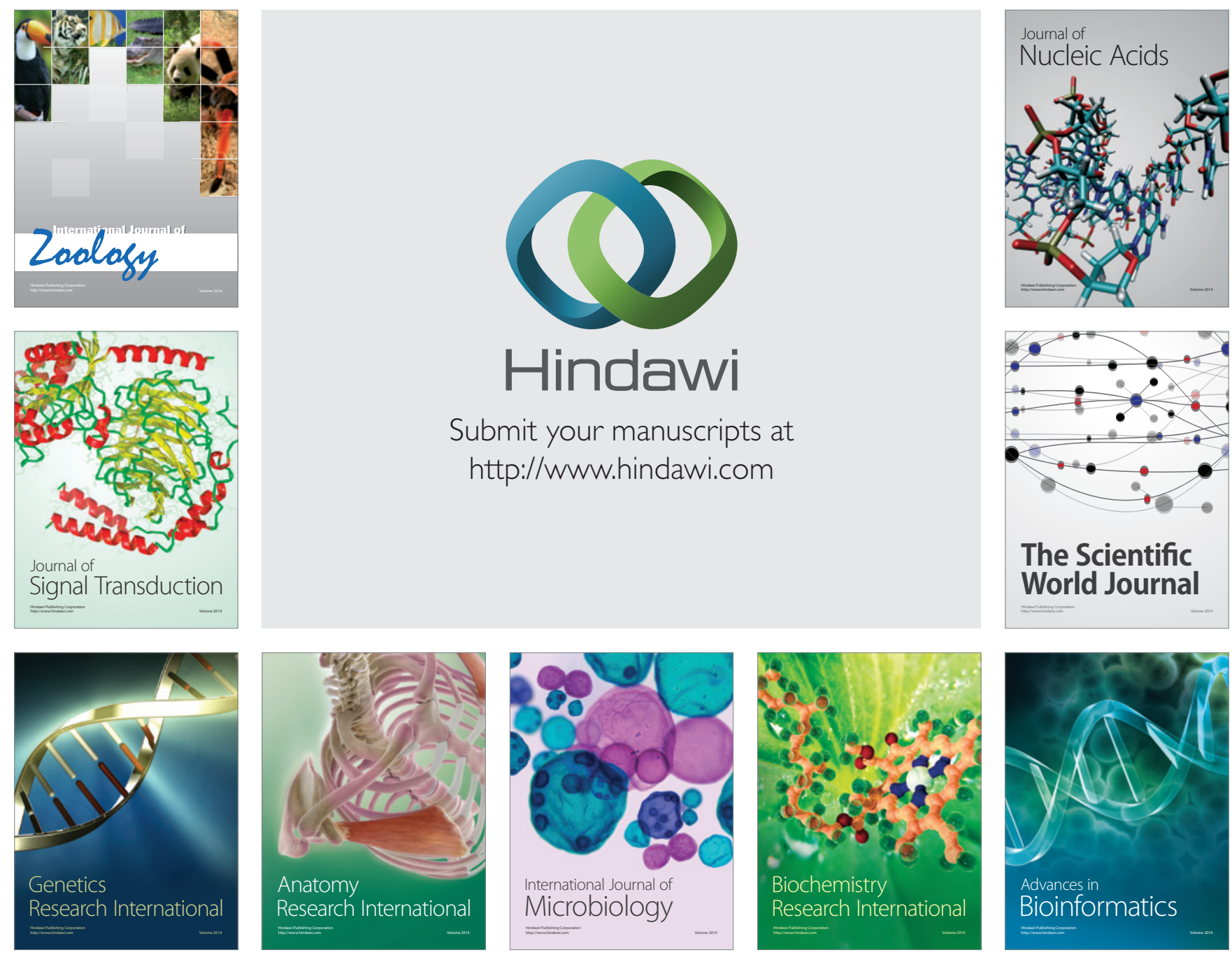

The Scientific World Journal
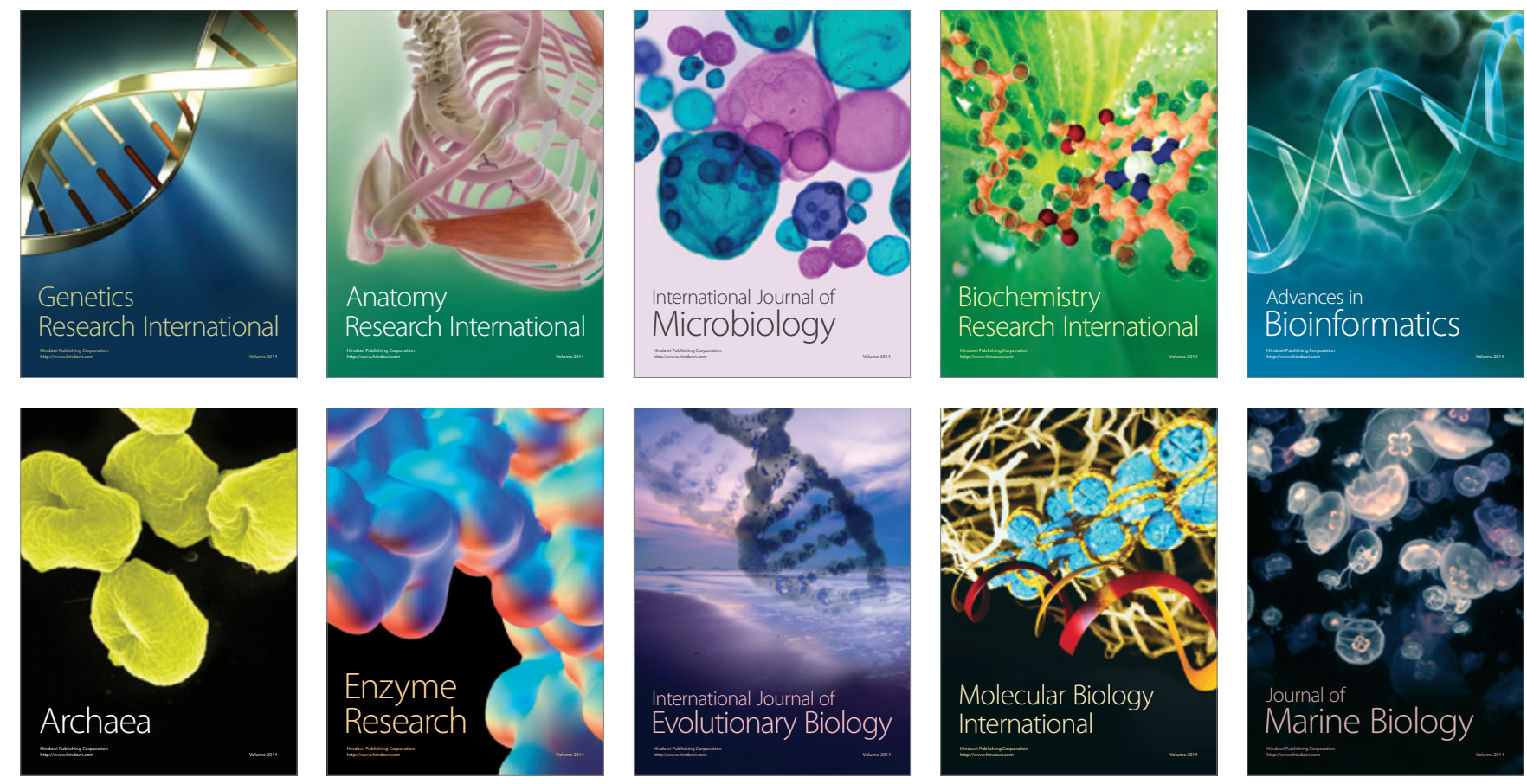